\title{
Hydrological sciences and water security: An overview
}

\author{
GORDON YOUNG ${ }^{1}$, SIEGFRIED DEMUTH ${ }^{2}$, ANIL MISHRA $^{2} \&$ \\ CHRISTOPHE CUDENNEC ${ }^{3}$
}

1 Past-President, IAHS, Department of Geography and Environmental Studies, Wilfrid Laurier University, Waterloo, Ontario, Canada

gordonyoung_wwap@yahoo.com

2 Hydrological Systems and Water Scarcity Section, Division of Water Sciences, Natural Sciences Sector UNESCO, 1 rue Miollis, F-75732 Paris Cedex 15, France

3 Secretary-General, IAHS, Agrocampus Ouest, INRA, UMR1069, Soil, Agro and HydroSystem, F-35000 Rennes, France

\begin{abstract}
This paper provides an introduction to the concepts of water security including not only the risks to human wellbeing posed by floods and droughts, but also the threats of inadequate supply of water in both quantity and quality for food production, human health, energy and industrial production, and for the natural ecosystems on which life depends. The overall setting is one of constant change in all aspects of Earth systems. Hydrological systems (processes and regimes) are changing, resulting from varying and changing precipitation and energy inputs, changes in surface covers, mining of groundwater resources, and storage and diversions by dams and infrastructures. Changes in social, political and economic conditions include population and demographic shifts, political realignments, changes in financial systems and in trade patterns. There is an urgent need to address hydrological and social changes simultaneously and in combination rather than as separate entities, and thus the need to develop the approach of 'socio-hydrology'. All aspects of water security, including the responses of both UNESCO and the International Association of Hydrological Sciences (IAHS) to the concepts of socio-hydrology, are examined in detailed papers within the volume titled Hydrological Sciences and Water Security: Past, Present and Future.
\end{abstract}

\section{THE SETTING}

Freshwater is a key resource for human health, prosperity and security. It is essential for poverty eradication, gender equality, food security, and the preservation of ecosystems. Yet billions of people worldwide are confronted with serious freshwater challenges, from water scarcity, poor water quality and lack of sanitation facilities, to water-related disasters such as floods and droughts. Almost half of the world's population will be living in areas with high water stress by 2030.

Water resources are under increasingly severe pressure from climate change and other global drivers. Climate change alters rainfall patterns, soil moisture, humidity, glacier-mass balance and river flow, and also causes changes to underground water sources. At the same time, floods and droughts are rising in frequency, intensity and severity. Unprecedented population growth, a changing climate, rapid urbanization, expansion of infrastructure, migration, changes in diet, land conversion and pollution translate into changes in fluxes, pathways and stores of water, and will create further pressures on water resources that will have a tremendous impact on the natural environment. Deteriorating water infrastructure in many parts of the world will further impact public health and the environment.

Global water issues are being recognized at very high level as of critical importance to human wellbeing and safety, to economic and social development and to the maintenance of natural ecosystems so vital to life on Earth. The importance of water issues is recognized within the United Nations system - the UN Secretary General has emphasized the critical importance of water, particularly in regard to drinking water supply and sanitation, and the Deputy Secretary General has highlighted critical water issues in a recent article in Nature (Eliasson 2015).

We live in a world of constant change and considerable uncertainty. The changes occur simultaneously, some the result of natural forces and some human-induced. Some are relatively slow and some are sudden. Some are predictable and others unexpected and take us by surprise.

\section{The evolution of human activities}

According to the recently released International Panel on Climate Change (IPCC) 5th Assessment Synthesis Report, human influence on the climate system is clear; anthropogenic influences have 
likely affected the global water cycle since the middle of the last century. With the projected global temperature increase, scientists generally agree that the global hydrological cycle will intensify and suggest, in particular, that the extremes of droughts and floods will become more common. The IPCC reflects this in its assessment of the vulnerability to the regional impacts of climate change (Watson et al. 1998). In many regions, changing precipitation or melting snow and ice are altering hydrological systems, affecting water resources in terms of quantity and quality (medium confidence) (IPCC Synthesis Report 2014).

Human activities are in a process of constant evolution. First and foremost, human populations have grown enormously - from 1 billion inhabitants some 200 years ago to over 7 billion at the present day; and the acceleration of overall growth in the past few decades has been remarkable. However, such simple statements give only half of the story for, while much of the less developed world is experiencing unprecedented population increases, other countries and regions, such as Japan and Eastern Europe, are witnessing significant declines in population. Further, there are very significant movements of population both within and between countries. More than $50 \%$ of the global population now lives in cities and, in many instances, such movements result in social disruption (see the World Bank data for more detailed information: http://data.worldbank.org/indicator/SP.URB.TOTL.IN.ZS). Sudden and dramatic urbanization poses huge problems for water supply - having dire repercussions for human health - especially in peripheral informal settlements. Mass movements of people between countries on a permanent, semi-permanent or seasonal basis also pose problems for water managers. Whether these are mass movements on a long-term basis, for example from Central America to the United States, or from North Africa or Eastern Europe into Western Europe, or migrant workers travelling from many Asian countries to the Gulf States, or simply seasonal tourists journeying, for example, from Northern to Southern Europe, demand for water in the recipient communities is often strained.

As globalization takes place and as advances in communication make our world ever more integrated and fast to respond to financial and economic crises, so we can, in a highly unpredictable fashion, find ourselves at the mercy of economic catastrophes such as that which beset us in 2008-2009. Such sudden changes can have far-reaching, worldwide political, social and economic consequences.

Political set-ups are also in a process of almost constant change. Some countries break up into smaller units while others merge into larger groupings. New trading blocs appear affecting interactions between countries while, at the same time, internal political restructuring may be taking place affecting not only internal trade and economic growth, but also interactions between countries. And, in the worst of circumstances internal political disruption may lead to civil unrest, often with disastrous consequences.

Unfortunately there are many regions of the world, particularly in the Middle East, that are now beset by serious internal conflict. In the last decade conflicts have taken on a new dimension with the rise of terrorist activities 'exporting' conflict to otherwise stable regions. Water supply systems are becoming targets for local and terrorist inspired warfare, e.g. wells in small villages in Darfur have been poisoned, forcing the migration of large numbers of people - and the battle for the Mosul Dam has been an emblematic episode. Groundwater resources are under threat through contamination of bombs in regions under war, e.g. in Iraq and Syria. A new approach to explore the human pressure on rivers worldwide at a fine spatial resolution is provided by Ceola et al. (this volume).

Such are the broad contexts within which we must consider hydrology and sustainable water resources management.

\section{The evolution of Earth systems}

In the realm of the Earth sciences, landscapes and topography evolve in conjunction with the evolution of ecosystems. Many of the processes of denudation and erosion, and those of sedimentation, are slow and persistent and to a large extent predictable; some, such as earthquakes and volcanic eruptions may be sudden, catastrophic and to a large extent unpredictable. Climates, 
too, may exhibit both longer and shorter trends and cycles of change, sometimes suddenly influenced by, for example, changes in sunspot activity or massive volcanic eruptions quickly changing energy inputs and perhaps inducing changes in the intensity and occurrence of precipitation.

It is widely recognized that human activities are influencing Earth systems in an unprecedented and very significant fashion. Paralleling the massive growth in human populations in the past 200 years, and particularly in the last few decades, there have been human-induced changes in the landscape, in the sub-surface and in the atmosphere. Changes in vegetation cover and the growth of human settlements and activities, with associated massive changes in ecosystems, are irreversibly altering the surface of the Earth. Extraction and consumption of water in combination with damming and the diverting of water-courses are having major consequences on rates of erosion and sedimentation, and having particularly detrimental consequences for the maintenance and development of deltas. Mining of minerals and water from underground sources are changing the sub-surface while also influencing surface conditions. The Earth's atmosphere is being significantly affected by the injection of greenhouse gases, with consequent changes to the climate system in turn affecting hydrological responses.

Such is the extent of human influence on Earth systems that the proposition of a new geological era - The Anthropocene - is being advocated and debated. Since this term was coined by Crutzen and Stoermer in the early 2000s, the concept has been extensively elaborated (Steffen et al. 2011) and is encompassing water issues, as further explained in the paper by Berkhout (this volume).

\section{Changes in hydrology}

Hydrology is changing as a result of both natural and human-induced changes. The climatic drivers of hydrological processes have been changing as a result of cycles and trends with durations over short to very long time periods. Until the last century or so, such changes were 'natural'; however, to an ever greater degree, over the last few decades human influences on climate have been increasing, leading to changes in energy inputs to the Earth's surface and probably influencing the location, duration, frequency and intensity of precipitation. Changes have been particularly evident in high latitude and high altitude locations where processes of snow and ice melt have been greatly affected with consequences for the regimes of many river systems. Illustration of the influences of changes in climate on water resources is given in the paper by Mondal and Mujumdar (this volume). The latest findings of the Intergovernmental Panel on Climate Change (IPCC) may be accessed at: http://www.ipcc.ch/report/ar5/wg2/.

In addition, and possibly more important than climate changes, have been the effects of human-induced changes to land cover, the construction of dams and diversions of rivers, and the mining of groundwater resources (Vörösmarty et al. 2010). The decline of groundwater due to overexploitation and the depletion of forests, the increases in farm land and the proliferation of human settlements, have been some of the more important elements of change greatly affecting runoff regimes. The widespread construction of dams and diversions are having enormous consequences - changing the probability of floods, having a great impact on sediment transport and deposition, and in general affecting the availability of water in quantity and quality for the many uses to which the resource is put - and also affecting the natural ecosystems on which humans ultimately depend. The mining of groundwater resources is recognized as a particularly important consideration in those many locations and regions in which groundwater is of paramount importance as a source of supply (see the paper by Chambel, this volume).

The management of the resource is becoming more and more difficult in those many regions in which the supply of water is being outstripped by demand and where the threats posed by water are increasing. The resource is used for many purposes - for the basic human needs of food production and for health, for the production of energy and for the needs of industries - and for the sustenance of the ecosystems on which all life depends. As more and more human settlements are being located in flood-prone areas, as populations grow and as in some areas, for example in the 
Cuvelei basin in Namibia, the occurrence, duration and intensity of floods increase, so the threats of flooding in terms of human life and livelihoods also increase. Low-lying coastal situations (in which there is a particular tendency for humans to settle) are becoming especially susceptible to flooding from both land and the oceans as sea-levels rise and as the frequency and intensity of storm surges increase. In order to monitor changes in hydrological regimes, data and information collected in a consistent fashion over extended time periods are required - Stewart (this volume) makes the case for the importance of monitoring procedures.

\section{The response of the hydrological community}

Over the last few decades there has been a growing realization that the hydrological sciences should not only consider the physical processes within hydrological systems, but should also consider the inter-linkages with social, political and economic processes. Clearly, the understanding of basic hydrological processes should underpin approaches to the efficient and effective management of water resources, but of equal importance are considerations of governance issues. Hence, we witness the evolution and broad acceptance of the concept of Integrated Water Resources Management that has now been widely adopted by most water managers. This evolution can be illustrated by examining the development of UNESCO's International Hydrological Programme (IHP) since its inception in 1975 after the International Hydrological Decade (IHD, 1965-1974). The Programme has evolved from an almost purely physically-based approach in understanding hydrological processes with little consideration of human influences, to the modern approach of 'socio-hydrology' that embraces the interaction of human activities with hydrological processes. As described in the paper by Jimenez-Cisneros (this volume) the IHD/IHP has developed under the following headings:

- Experimental Basins, Categorization of Large Floods, World Water Balance (1965-1974)

- International Cooperation in Hydrological Sciences (1975-1990)

- Hydrology and Water Resources Sustainable Development in a Changing Environment (1990-1996)

- Hydrology and Water Resources Development in a Vulnerable Environment (1996-2002)

- Water Interactions: Systems at Risk and Social Challenges (2002-2008)

- Water Dependencies: Systems under Stress and Social Responses (2008-2014)

- Water Security: Responses to Local, Regional and Global Challenges (2014-2021)

The same evolution of approach has been adopted within IAHS. The current decade of research (2013-2022), initiated within IAHS, is entitled 'Panta Rhei' meaning 'everything changes' - there are constant and consistent changes both within society and within hydrology. These changes are intimately interlinked and inter-dependent. Details of the IAHS decade of research are found in the paper by Savenije (this volume) and may be accessed at: http://distart1 19.ing.unibo.it/pantarhei/ ?q=node/ 1 and in Montanari et al. (2013).

The overall concept of Water Security and the 'socio-hydrology' approach is well elaborated and illustrated in the paper by Wheater (this volume).

\section{THE CONCEPT OF WATER SECURITY}

\section{Security broadly defined}

As a general concept 'security' can be very broadly defined and has many dimensions. The United Nations system and national governments worldwide are paying great attention to security of populations from physical conflict whether that be warfare between nations, strife within nations or the 'export' of conflict through terrorist activities. This broad conceptual setting of security is further discussed in the paper by Kundzewicz and Matczak (this volume). Other broad dimensions of security include the security of freedom of thought, speech and expression, freedom of movement within and between countries and freedom of trade. Security from natural disasters is a 
further dimension of the suite of security issues. These may include health 'disasters' such as the Ebola crisis in West Africa and natural disasters ranging from earthquakes, volcanic eruptions and tsunamis to floods and droughts.

The United Nations International Strategy for Disaster Reduction (UNISDR) is mandated to serve as the focal point in the United Nations system for the coordination of disaster reduction, and to ensure synergies among the disaster reduction activities of the United Nations system and regional organizations and activities in socio-economic and humanitarian fields. Clearly, this mandate is confined to naturally occurring disasters and does not include the issues surrounding warfare and health.

The 'Hyogo Framework for Action 2005-2015: Building the Resilience of Nations and Communities to Disasters' was adopted by the World Conference on Disaster Reduction, held in Kobe, Hyogo, Japan, in January 2005 (see: http://www.unisdr.org/2005/wcdr/intergover/officialdoc/L-docs/Hyogo-framework-for-action-english.pdf).

In 2015 the Third UN World Conference on Disaster Risk Reduction (DRR) is to be held in Sendai, Japan. The purpose of the Conference is to review progress made on DRR since the Kobe conference and to elaborate the framework for action in coming years. Clearly water-related disasters of floods and droughts will feature importantly in the discussions and recommendations.

Thus, water security is a sub-set within a broader range of security issues.

\section{Water security}

Water Security is defined by the International Hydrological Programme of UNESCO as "the capacity of a population to safeguard access to adequate quantities of water of acceptable quality for sustaining human and ecosystem health on a watershed basis, and to ensure efficient protection of life and property against water related hazards - floods, landslides, land subsidence and droughts" (UNESCO-IHP 2012), which was further reiterated by UN-Water in its policy brief on Water Security and the Global Water Agenda (UN-Water 2013). Thus, Water Security not only addresses the threats posed by floods, droughts and pollution spills to human societies, but also includes the impacts of inadequate supplies of water, both in quantity and quality, for their critically important support to food and energy production, for domestic and industrial purposes and for sustaining ecosystem productivity. The UNESCO approach to water security is further discussed in the paper by Jimenez-Cisneros (this volume).

Water security is becoming entrenched in the activities and mandates of many water-related non-governmental organizations and cooperation between such organizations is underway. Thus, in 2013 during the Congress of the International Association for Hydro-Environment Engineering and Research (IAHR), seven major international water associations (including IAHS) signed a 'Global Water Security Declaration' in the presence of UNESCO's Natural Science Sector. The Declaration, recognizing the need to address water security issues, committed the signatories to improving water security through coordinated action on: development of relevant policies, promoting education on water issues at all levels, promoting relevant thematic research, and through encouraging engineers and other professionals to work on the design of sustainable hydroenvironmental systems. The declaration may be found at: http://www.iahr.org/uploadedfiles/ userfiles/files/Declaration_A3.pdf.

Water security issues may be conveniently broken down into water as a threat (floods, droughts and pollution issues) and security of supply for the very many uses for which the resource is utilized.

\section{Security from water as a threat}

\section{Threats from floods}

There are many different types of floods resulting from a number of causative factors. This leads to floods of differing timing, frequency, intensity and duration. Some floods are highly predictable and may be forecast some time in advance of occurrence with considerable accuracy, while other 
floods are highly unpredictable and may cause severe and unanticipated harm. Direct damage to human life and livelihoods will vary according to the location of human activities in flood-prone areas. Floods directly affecting one area of a country or region may have indirect costs for the whole country or region as a result of cascading economic damage. But floods can also bring benefits to flood plain areas including the role small floods play in the maintenance of flood plain fertility and the importance of regular flood flows to in-stream ecosystems.

A typology of floods would include events with a variety of origins:

- classical rainfall induced floods that would range from localized flash floods, for example sudden, short-term floods in desert wadis, to massive floods of long duration, for example the extensive and common flooding over large areas in low-lying monsoon regions;

- snow- and ice-related floods, particularly common in high latitude and high altitude regions and ranging from snow-melt floods (that may be made more intense if occurring over frozen ground) to glacier lake outburst floods and jökulhlaups the effects of which may be felt in downstream low-lying areas adjacent to mountain systems, and to flooding due to river-ice jams;

- dam burst floods resulting from the collapse of either artificial dams or levees, or from the collapse of dams due to earth slides or created by masses of vegetation detritus temporarily damming a river channel;

- floods grade into landslides, mudflows and lahars in particular circumstances;

- ocean-related floods in coastal zones may be particularly destructive in the case of tsunamis and storm surge floods;

- floods are often of multiple origins resulting from the combination of one or more of the above elements.

The topic of floods is treated more fully in the paper by Kundzewicz and Matczak (this volume). More information on risks from water may be found in the 2 nd World Water Development Report, Chapter 10 (UN-WWAP 2006).

\section{Threats from droughts}

There are many definitions of drought and droughts may be categorized as meteorological, soilmoisture or agricultural, hydrological and socio-economic. Meteorological drought is specific to particular regions and may be defined as long periods when precipitation is significantly below normal for the region. Soil-moisture or agricultural drought occurs when there is insufficient water at particular stages of the growing season for plants. Hydrological drought occurs when water volumes in watercourses are significantly below normal for long time periods or below a given threshold. Socio-economic drought occurs when the supply of water is insufficient for the demand, e.g. for the energy sector.

While the commonly held concept of drought is when there is insufficient water to drink or for food production, many other human activities are threatened by drought. For example electricity generation may be threatened by insufficient water to run hydro-power facilities or for cooling of thermal power plants, navigation may be threatened by low water levels in lakes and rivers, and industrial production may be threatened for those processes requiring water supply and for transportation. The concepts and implications of droughts are developed more fully in the paper by Kundzewicz and Matczak (this volume). The particular problems associated with very dry desert regions are illustrated for the Middle East and North Africa region in the paper by Nacken (this volume).

\section{Threats from water pollution}

While sufficient quantities of water for particular uses are of fundamental importance for human well-being and livelihoods, the quality of the resource is also of great importance and, in many situations, is of growing importance. Water quality requirements and acceptable standards vary greatly according to the particular use. Supplies of drinking water need to be of very high quality, 
requirements for crops may be somewhat lower; supply for hydro-power production should be sediment free but may tolerate chemical pollution. Water in river and lake systems used for shipping may have very low quality requirements.

The types of pollution are many, ranging from overload of organic matter, nutrients, pathogens and microbial contaminants, through salinization and acidification to toxic compounds and heavy metals. In addition, thermal pollution due to cooling systems for thermal and nuclear plants and suspended sediment that may be increased inter alia by changes to vegetation cover, affect natural ecosystems and numerous human endeavours.

Sources of pollution range from human, industrial and farming waste to energy production. Those sources may be gradual but persistent, such as through the application of herbicides and pesticides, and may affect both surface waters and groundwaters. On the other hand, some sources of pollution may be sudden and catastrophic, for example the sudden release of toxic sludge through failure of dikes around a tailings pond, or release of oil through a break in a pipeline.

A thorough accounting of freshwater pollutants is given in the $2 n d$ World Water Development Report, Chapter 4 (UN-WWAP 2006). Water quality governance issues are treated by Tundisi et al. (this volume) and further examples of oil spills may be found in the paper by Barenboim et al. (this volume).

\section{Security from inadequate water supply}

Water is essential for almost all human activities - for basic human well-being, for economic and social development. Water is also vital for the maintenance of the natural ecosystems on which we all ultimately depend. Water managers must be concerned with a large variety of issues and human needs and these must always be balanced with consideration for the natural environment.

There has been some confusion within water security-related discussions as the expression 'water resources' has been commonly used as a synonym for 'river/groundwater flow' - this important issue is treated in the paper by Andréassian et al. (this volume). Despite this confusion it is clear that a set of basic water needs may be defined as follows:

- Water for basic human needs Clearly water is of fundamental importance for food production, whether for agriculture, the raising of livestock or for aqua-culture. Water is vital for health for drinking, for sanitation and for hygiene, and many diseases, such as malaria and cholera, are water-related (UN Millennium Project 2005). Thus water adequate in both quantity and quality underpins nutrition, health and basic quality of life. To a great extent these issues have been successfully addressed in more developed countries, but this is far from the case in the less developed world.

- Water for social development Social development includes the provision of education and health care. Without clean water supplies and good sanitation facilities in schools and hospitals, social development is stymied - and in less developed countries this is all too often the case. Education is a prerequisite for economic growth and, in schools without sanitation facilities, it is girls who suffer most and are therefore disadvantaged, introducing an important gender element into the equation.

- Water for economic development Underpinned by basic human health and social development, water is of fundamental importance for economic development through energy and industrial production. Water is needed for many forms of energy production - for hydro power and for cooling of thermal and nuclear power stations. And energy, in turn, is needed for pumping, including extraction of water from aquifers. The water and energy 'nexus' is addressed in detail in the paper by Miletto (this volume). Water is needed for many industries and those industries in turn have effects, through pollution and abstraction, on water quality and quantity that affects both downstream users and natural ecosystems. A recent and growing water use in some industrialized countries is in non-food agriculture, in particular recent shifts towards growing biofuels which have significant implications for water resources management.

- Water and natural ecosystems Water is critical to the sustenance of natural ecosystems that are of fundamental importance to human well-being and development (UNEP 2006). We 
destroy or degrade these natural systems at our peril, and so social and economic development and basic human betterment must go hand in hand with preservation of the natural environment (UN-Water 2008).

Complexity is added to the four major issues listed above when it is realised that there are major upstream/downstream dependencies that are especially crucial in internationally-shared river basins; that interactions between land-based and marine systems are complex and of vital importance especially to the large numbers of people living in deltaic and estuarine areas; and that in a very real sense water knows no boundaries - water is essentially exported through the transportation of agricultural produce (crops and livestock) created in one region or country and sold in other parts of the world.

These issues of threats from water and the adequacy of water supply for multiple uses are not independent of each other - they are interlinked and thus must be treated in an integrated manner. This is the rationale for Integrated Water Resources Management (IWRM), the most widely accepted definition of which is that given by the Global Water Partnership: "IWRM is defined as a process that promotes the coordinated development and management of water, land and related resources, in order to maximize the resultant economic and social welfare in an equitable manner without compromising the sustainability of vital ecosystems" (GWP 2004). The IWRM approach has now, in large measure, been accepted internationally as the way forward for efficient and sustainable development and management of the world's limited water resources and for coping with conflicting demands (UN-Water 2012). While policies should be developed with an IWRM approach, it is also essential to develop necessary infrastructure - dams, diversions, dikes, etc. - in order to control water supply and reduce and mitigate the effects of extreme events; the paper by Huang (this volume) makes the case very convincingly for the necessity of infrastructure development.

\section{CONCLUDING REMARKS}

2015 will be a year of critically important negotiations within the UN system and at all national and international levels as the Sustainable Development Goals (SDGs) are developed for the post2015 agenda. The UN General Assembly Open Working Group on SDGs (OWG 2014) has proposed 17 goals and 169 corresponding targets as SDGs and there is a dedicated goal on water: Goal 6: "Secure water and sanitation for all for a sustainable world". In addition, climate change prevention, mitigation and adaptation measures will be discussed at the COP-21 meetings in Paris in 2015. Water security issues will be essential components of these major debates - their high prominence on all agendas is well justified.

\section{REFERENCES}

Andréassian, V. et al. (2015) What part of natural flow can be considered a 'water resource'? In: Hydrological Sciences and Water Security: Past, Present and Future (ed. by Cudennec, C. et al.), PIAHS 366, 86-92.

Barenboim, G.M. (2015) New problems and opportunities of oil spill monitoring systems. In: Hydrological Sciences and Water Security: Past, Present and Future (ed. by Cudennec, C. et al.), PIAHS 366, 64-74.

Berkhout, F. (2015) Anthropocene Futures and Water Security. In: Hydrological Sciences and Water Security: Past, Present and Future (ed. by Cudennec, C. et al.), PIAHS 366, 31-33.

Ceola, S. et al. (2015) Human pressure on rivers is increasing worldwide and threatens water security. In: Hydrological Sciences and Water Security: Past, Present and Future (ed. by Cudennec, C. et al.), PIAHS 366, $109-110$.

Chambel, A. (2015) The role of groundwater in the management of water resources in the world. In: Hydrological Sciences and Water Security: Past, Present and Future (ed. by Cudennec, C. et al.), PIAHS 366, 107-108.

Eliasson. J. (2015) The rising pressure of global water shortages. Nature 517(7532), http:/www.nature.com/news/the-risingpressure-of-global-water-shortages-1.16622.

GWP (Global Water Partnership) (2004) Catalyzing Change: A Handbook for Developing Integrated Water Resources Management (IWRM) and Water Efficiency Strategies. Stockholm, GWP Technical Committee.

Huang, Y. (2015) Integrated water resources management using engineering measures. In: Hydrological Sciences and Water Security: Past, Present and Future (ed. by Cudennec, C. et al.), PIAHS 366, 54-63.

Jimenez-Cisneros, B. (2015) Responding to the challenges of water security: the Eighth Phase of the International Hydrological Programme 2014-2021. In: Hydrological Sciences and Water Security: Past, Present and Future (ed. by Cudennec, C. et al.), PIAHS 366, 10-19. 
Kundzewicz, Z.W. and Matczak, P. (2015) Hydrological extremes and security. In: Hydrological Sciences and Water Security: Past, Present and Future (ed. by Cudennec, C. et al.), PIAHS 366, 44-53.

Miletto, M. (2015) Water and Energy nexus: findings of the World Water Development Report 2014. In: Hydrological Sciences and Water Security: Past, Present and Future (ed. by Cudennec, C. et al.), PIAHS 366, 93-99.

Mondal, A. and Mujumdar, P.P. (2015) Regional hydrologic impacts of climate change: implications for water management in India. In: Hydrological Sciences and Water Security: Past, Present and Future (ed. by Cudennec, C. et al.), PIAHS 366, $34-43$.

Montanari, A., et al. (2013) "Panta Rhei-Everything Flows": Change in hydrology and society-The IAHS Scientific Decade 2013-2022. Hydrological Sciences Journal 58(6) 1256-1275. doi: 10.1080/02626667.2013.809088

Nacken, H. (2015) Capacity building for hydrological change - using a blended learning approach. In: Hydrological Sciences and Water Security: Past, Present and Future (ed. by Cudennec, C. et al.), PIAHS 366, 100-106.

Savenije, H.H.G. (2015) Panta Rhei, the new science decade of IAHS. In: Hydrological Sciences and Water Security: Past, Present and Future (ed. by Cudennec, C. et al.), PIAHS 366, 20-22.

Steffen, W., et al. (2011) The Anthropocene: conceptual and historical perspectives. Phil. Trans. Royal Soc. A 369, $842-867$.

Stewart, B. (2015) Measuring what we manage - the importance of hydrological data to water resources management. In: Hydrological Sciences and Water Security: Past, Present and Future (ed. by Cudennec, C. et al.) PIAHS 366, 80-85.

Tundisi, J.G. (2015) Water availability, water quality water governance. In: Hydrological Sciences and Water Security: Past, Present and Future (ed. by Cudennec, C. et al.), PIAHS 366, 75-79.

UN Millennium Project (2005) Health, Dignity and Development: What Will it Take? Task Force on Water and Sanitation. http://www.unmillenniumproject.org/documents/What_Will_It_Take.pdf

UNEP (United Nations Environment Programme) (2006) Marine and Coastal Ecosystems and Human Wellbeing: A Synthesis Report Based on the Findings of the Millennium Ecosystem Assessment. http://www.unep.org/pdf/Completev6_LR.pdf

UNESCO-IHP (2012) http://unesdoc.unesco.org/images/0021/002164/216434E.pdf

UN-Water (2012) Status Report on the application of Integrated Approaches to Water Resources Management for Rio+20 http://www.unwater.org/publications/publications-detail/en/c/204523/

UN-Water (2013) Water Security and the Global Water Agenda. United Nations University, UN-Water Analytical Brief, 01/2013. http://www.unwater.org/publications/publications-detail/en/c/197890/

UN-WWAP (United Nations World Water Assessment Programme) (2006) UN World Water Development Report 2: Water, a shared responsibility. Paris, New York and Oxford. UNESCO (United Nations Educational, Scientific and Cultural Organization) and Berghahn Books. http://www.unesco.org/new/en/natural-sciences/environment/water/wwap/wwdr/ wwdr2-2006/downloads-wwdr2/

Vörösmarty, C.J., et al. (2010) Global threats to human water security and river biodiversity. Nature 467(7315), 555-561. doi: 10.1038/nature09440

Watson, R.T., Zinyowera, M.C. and Moss, R.H. (eds) (1998) The Regional Impacts of Climate Change: An Assessment of Vulnerability. IPCC. Cambridge University Press: Cambridge.

Wheater, H.S. (2015) Water Security - science and management challenges. In: Hydrological Sciences and Water Security: Past, Present and Future (ed. by Cudennec, C. et al.), PIAHS 366, 23-30. 